\title{
The Sight of the Nurse about the Availability of Transport Services in the Urgencies of the Primary Health Care

Amanda Soares ${ }^{1}$, Olga Feitosa Braga Teixeira ${ }^{2}$, Thiago Lívio Barbosa Pereira ${ }^{3}$, Bárbara Letícia de Queiroz Xavier ${ }^{3}$, Tito Lívio Ribeiro Gomes do Nascimento ${ }^{4}$, Najara Rodrigues Dantas ${ }^{1}$, Angélica da Silva Soares ${ }^{5}$, José Iran Oliveira das Chagas Júnior ${ }^{6}$, Flaviana Dávila de Sousa Soares7, Ícaro Tavares Borges ${ }^{1}$, Ana Cláudia Martins Rodrigues ${ }^{3}$, Brenda dos Santos Teixeira ${ }^{3}$, Paula Frassinetti Oliveira Cezário ${ }^{8}$, Anna Mikaelly de Sousa Tavares Assis ${ }^{9}$, Maria Mônica Paulino do Nascimento ${ }^{10}$, Denise Pinheiro Leite ${ }^{11}$

\section{Abstract}

Introduction: The emergence of failures in transport organization is related to the lack of planning by the managers responsible for the distribution of financial resources, which causes numerous losses to patients and health professionals, particularly in the context of primary care.

Objective: Identifying the availability of transport for users in cases of urgency in Basic Units according to the reported by nurses.

Method: This is a study of a qualitative approach, performed with 08 nurses of the Family Health Strategy. Data were collected through interviews with structured questionnaire and analyzed according to Thematic Content Analysis.

Results: The data emerged from the interviews state that there is the provision of transport; however, these are inappropriate, because the type and the waiting time, particularly for the units of the countryside.

Conclusion: The lack of adequate transport takes to a deficit in user's healthcare, requiring a greater commitment of managers with planning and health management in their municipality.

1 Regional University of Cariri/Decentralized Unit of Iguatu. Iguatu, Ceara, Brazil.

2 Health Technical School of Cajazeiras, Federal University of Campina Grande. Cajazeiras, Paraiba, Brazil.

3 Bachelor of Nursing, Federal University of Campina Grande. Cajazeiras, Paraiba, Brazil.

4 Postgraduate Nursing Program (stricto sensu), State University of Southwest Bahia. Jequie, Bahia, Brazil.

5 Physiotherapy Student, Faculty Santa Maria. Cajazeiras, Paraiba, Brazil.

6 Postgraduate Program (lato sensu) in Public Health, University of Fortaleza. Fortaleza, Ceara, Brazil.

7 Postgraduate Student in Intensive Care Unity, Faculty Santa Maria. Cajazeiras, Paraiba, Brazil.

8 Specialist, Federal University of Paraiba, João Pessoa, Paraiba, Brazil.

9 Nursing Student, Federal University of Paraiba. João Pessoa, Paraiba, Brazil.

10 Master Student of Collective Health, Catholic University of Santos. Santos, São Paulo, Brazil.

11 Nursing Student, Regional University of Cariri/Decentralized Unit of Iguatu. Iguatu, Ceara, Brazil.

Contact information: 


\section{Introduction}

The organization of regionalized health services networks formed the premise about which historically the proposed reform of the Brazilian health system have been debated, forming part of the belongings of health planning for decades. However, throughout the 1990s, by the very course of the decentralization process, the establishment of networks ceased to be the central axis around which it built the service organization, returning to the center of the debate from the publication of the Standard Operational Health Care in 2000, and especially with the Pact for Health in 2006 [1].

The care networks organized health care of the population so that services were linked to each other by a single mission, common goals and a cooperative and interdependent action, allowing offer a continuous and comprehensive care to a given population. In order to fulfill the principle of universality and fairness of the National Health System in 2003 approved the National Policy for Urgency being assigned to each level of care, responsibilities for certain portion of the population in urgency demand, as the limits of its complexity and ability to solve [2-3].

Conceptualizing urgency, one can set it as the occurrence of unexpected health problem with or without potentially life whose carrier needs immediate medical attention. In this case, the Primary Care being constituent of the network urgencies, qualified as a fixed pre-hospital component enables immediate response to urgent low and medium complexity, welcoming cases and classifying them, providing first aid. Thus, professionals in the Primary Care should be prepared to recognize urgencies in its area of operation [4-6].

To the effectiveness of urgency attendances in Primary Care, it is necessary to guarantee material resources, staff training and an adequate transportation to the unit's needs. According to the Federal Council of Medicine Resolution $N^{\circ} 1.671 / 03$, the health system must ensure an ambulance to support pre-hospital services and training for every professional who works in the transport of patients [7].

Considering the impossibility of transport and its realization inadequate and time-consuming way can lead the patient to death or result in irreversible consequences, it sought through this study identify the availability of transport for urgencies occurred in Basic Health Units according to the report of nurses.

\section{Method}

The methodological approach followed was the qualitative approach, being carried out in Basic Health Units (BHU) belonging to the Strategy of Health of the municipality of Varzea Alegre, located in the South Central region of the State of Ceara. The population consisted of all nurses working in primary care, and selected 8 (eight) participants after the use of the inclusion/exclusion criteria.

Inclusion criteria were: being in the $\mathrm{BHU}$ at the time of completion of the research and not be away temporarily or permanently from service.

Data were collected through interviews with structured questionnaire, in the period from September to October 2014, with the following guiding question: "Does the health unit in which services are provided offer transfer/appropriate vehicle to transfer users to the secondary care in cases of urgency?"

The interviews were transcribed in full, and the data analyzer according to Thematic Content Analysis, which is divided into three stages defined by: pre-analysis (systematization of initial ideas, resorting to repeated and exhaustive reading, in order to get closer the material); material exploration (codification of material, by predefined rules) and treatment of results/data interpretation [8]. The speeches of the participants were identified by the letter " $E$ " followed by the ordinal number 
corresponding to the interview order $(E 1, E 2, \ldots)$ tending to preserve the anonymity of participants.

The research project was approved by the Research Ethics Committee of the Faculty Santa Maria/ FSM/Paraiba with opinion $N^{\circ} 1.027 .222$, complying with all the provisions of Resolution $N^{\circ} 466 / 12$ of the National Health Council.

\section{Results}

\section{Characterization of the research participants}

The study included 8 (eight) nurses, most of which was inserted between the ages of 25 and 34 years old and had service in the Family Health Strategy ranging from 6 to 10 years ( $50 \%$ for both), as shown in Table 1.

Table 1. Distribution of interviewed regarding gender, age and length of service in the $\mathrm{Fa}$ mily Health Strategy, Varzea Alegre-CE, 2014. $(n=8)$

\begin{tabular}{l|c|c|}
\hline \multicolumn{1}{|c|}{ Variables } & n & $\%$ \\
\hline Gender & & \\
\hline Female & 8 & 100 \\
\hline Male & - & - \\
\hline Age (in years) & & \\
\hline $25-34$ & 4 & 50 \\
\hline $35-44$ & 3 & 37.5 \\
\hline $45-54$ & 1 & 12.4 \\
\hline Length of service in the FHS (in years) & \\
\hline $1-5$ & 2 & 35 \\
\hline $6-10$ & 4 & 50 \\
\hline $11-20$ & 1 & 12.5 \\
\hline $21-30$ & 1 & 12.5 \\
\hline Total & 8 & 100 \\
\hline & Legend: FHS - Family Health Strategy \\
& Source: A field research, 2014.
\end{tabular}

\section{Availability of transport for transfer of patients in urgency situations}

For transporting patients in urgency situations, there was reported by the majority of the nurses, the use of the Municipal Department of Health vehicles; however, these are not available in a timely manner, so that the professional and users opt to use of private transportation for quick transfer to the secondary service.

Transportation is just from the Department of Health, we have to call if we have any transportation in the office, come. But if we need and if in the Health Department do not have transportation, it must our own [...], I took a lot in my car, because generally we call and there also has no willingness [...].

Usually we have transportation. Because of the delay we take our own transportation.

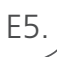

A car at the disposal of the unit at all times there is not. When we professionals need to transfer a patient to the hospital, he goes on his own.

The transport issue is of the responsibility of the Health Department, which sometimes does not have any vehicle or driver for an immediate transfer.

The questioning also covers BHUs in the countryside, being more distant from a highly complex service should have a more dynamic service, aiming at solving the local problems. Nurse's speech 02 highlights the lack of accessibility to the network of services, which, despite the existence of municipal ambulances, their use is limited to patients in the urban area, considering that these are stored in the county seat. 
The municipality has ambulances to transport the patient from his residence to the hospital or Basic Health Unit to the hospital; however, as work in the countryside and we cannot call the responsible sector and the delay of arrival to the site, usually transportation is done in the car that leads health professionals to the unit. Then, the driver of FHP takes the patient, if necessary, the nursing technician goes with the patient in the car, to the hospital.

E02.

\section{Discussion}

It was observed that there is a predominance of female nurses, highlighting the existing reality in most of this professional field. Despite the expressiveness of the data, the generalization of nurses' class as exclusively female is inappropriate, because men also work in the nursing profession, though in a smaller quantity. A man faces entrenched prejudice and imposed by society, as far as the feminization of nursing, is challenging and tends to decrease the demand for these by the nursing profession.

Nursing was the first university female profession in Brazil, designed to give sustainability to public health programs and support to health services. The divided image of women "home" due to social struggles coincided with the stabilization of the nursing profession, which made the woman of the nineteenth century in search of autonomy, engaging in nursing because the requirements were not complex like other professions [9].

It is observed that female characterization in the category of nurses is also proven in research [10] performed with Graduate Course of Nursing students, Faculty of Medicine of the $A B C$ Foundation in Santo André - SP, where 92, 44\% of students were female.

The age range presented by $50 \%(n=4)$ of the nurses was between 25-34 years old, which corro- borates the data from the survey [11] conducted by the National Council of Nursing in 2010, which states that the majority $(35.98 \%, n=521.527)$ of nurses in Brazil is among the age group 26-35 years old, implying that stage as the pinnacle of productive force and productive professional.

A wide range of factors explains the predominance of nursing professionals in the age group described above, the search for financial stabilization, developed in nursing the need to dedicate themselves to the service with greater commitment, constantly seeking scientific improvement and practical, gaining agility, which does stay longer inserted in the institution.

The time of service in primary care lies mostly in the range of 1 (one) to 10 years, totaling $75 \%(n=6)$ of the participants. The analyzed data are similar to a survey [12] carried out in the core network of Porto Alegre - RS, showing that approximately $77 \%(n=40)$ of nurses present the same period of activity in BHUs.

The insertion of the Health Care Networks provided the health care organization in integrated systems that can respond with effectiveness, efficien$c y$, safety, quality and equity, the health conditions of the population [13].

The increased demand for care throughout the care network by adding the determinations established by Care National Policy for the Emergency demanded the Basic Professional Attention knowledge about the health units that make up the network of care urgencies, not limited to hospital as the only system gateway, and managers to comply with all the requirements established by policy [14].

For the realization of urgent care when it is not capable of resolution in primary care, transportation assistance is necessary to ensure continuity of care. It emphasizes the need for this service in a context both quantitative and qualitative, due to recommendations that are required for the transfer of patients preventing those who are conducted by inadequate transport. 
Lack of transportation in the Basic Health Units, makes the integrated care in poor health, resulting in the absence or shortage of nursing care for users who need to monitor highly complex. The demands require that in all health facilities, whether basic or secondary care, have the help of a unique transport continues to care. Thus, recommended activities for nurses of Primary Care as the reference and counter reference, are made vulnerable by the arrangement of how the user is allocated in the network services [15].

The ordinance $\mathrm{N}^{\circ} 2,048$ in his chapter $\mathrm{VI}$, says that after the stabilization of a patient in a unit of low complexity, forwarding this to a specialist/ structured service should be provided immediately, but must also be guaranteed support for the return of patients outside the emergency situation on discharge are unable to move around because of his medical restrictions [16].

The client transfer delay of one unit to another is a factor that interferes with the quality of care, generating unresolved cases, which can result in severe consequences and deaths. Therefore, it is necessary to consider the distances between municipalities of small and medium-sized and reference municipalities and highly complex at the time of transfer [17].

In India, significant cases on the delay or unavailability of health care transport are evidenced by the high rates of maternal mortality, as well as the quantitative low institutional transfers. About $10.4 \%$ of cases of poor care pregnant women are related to inadequate transportation. Although $71 \%$ of Indian villages having primary care centers, only $55.5 \%$ had help of some urgency transport service [18]. The exposed situation demonstrates the need to support the care network with the necessary resources for assistance. In Brazil, there is a pertinent need to studies that relate the effectiveness of urgency transport with mortality data and sociodemographic factors, which prevents one from exploring what their real effects.
The locality of the population homes interferes with the degree of urgent care needs, characterizing them according to the risks to which they are exposed. The rural population plays risky and unhealthy activities for executing various activities without the use of personal protective equipment, in addition to desktop and leisure be enabler of various occupational risk factors, such as orthopedic disorders, muscle and skin [19]. Thus it can be seen that the welfare aid of urgency for rural community demands a special attention of managers, focusing on care planning, and priorities for each region.

Complementary strategies may be associated to reduce clinical complications in patients, especially in those units without the aid of transport, an example is the use of screening to ascertain the real necessity of the transfer and not allow the delay of care. Screening should emphasize the perception of risk, expanding the knowledge of unanticipated through signs and health symptoms [20].

Seen the need to expand the units to offer urgency services, wonders about what keeps at the level of management, the inclusion of the National Attention to Emergencies policy in primary care that was instituted in 2006, and its main ordinances of 2002 and 2003, after nine years of its implementation, it is inefficient to support a transport to urgency at BHU. A deficiency that generates losses at all levels of care, generating the consequences mainly for users of the health system [21].

As the Regulation of Emergency Medical pact between the services must ensure the support of transfers with ambulances, fast, safely and with quality. The fact is that usually found lacking health services in materials, human resources and physical structure, away from the envisaged by law [22]. In the case of health care facility located in the countryside, even with the protection of a Basic Support Unit of the Mobile Emergency Service, would not be enough to solve the problem as the difficulty to streamline the user's transfer would remain for be 
located in urban areas, a situation that requires a plan that aims to meet the demands of all users.

The forwarding of user inside the network of attention have organizational standards to be effected successfully. Before removing the user must make sure that all been exhausted technological features of the unit, as well as checking their clinical stability and define the most suitable transport, the choice being made according to the needs. For the path it is necessary to provide the accompaniment of a professional so that the revaluation is carried out along the way and the user-responsibility must be maintained for this until another team takes care [23].

\section{Conclusion}

Faced with the exposure of operations, highlights the worrying questioning the availability of vehicles suitable for Primary Care, primarily for the purpose of transferring customers requiring more complex care. The lack of a unique transport to the Basic Health Units takes the provision by the Secretary of Municipal Health ambulances and other vehicles, which are assigned to units where possible. The fact that there are few ambulances, compromises patient care network with urgent state, violating the principles of universality and equity of the Unified Health System.

Thus ensuring resources for transportation in emergencies should be organized through the development of a care plan to health systemized and implemented, favoring nursing interventions to ensure the quality and effectiveness of care and enabling an urgent/emergency care early, which reflects in a better prognosis for the user.

\section{References}

1. Kuschnir R, Chorny AH. Redes de atenção à saúde: contextualizando o debate. Ciênc Saúde Coletiva [Internet], Rio de Janeiro, 2010 Aug; 15(5): 2307-16. DOI: http://dx.doi. org/10.1590/S1413-81232010000500006

2. Mendes EV. As Redes de Atenção à Saúde. Ciênc Saúde Coletiva [Internet], Rio de Janeiro, 2010 Aug; 15(5): 2297-305. DOI: http://dx.doi.org/10.1590/S1413-81232010000500005

3. Soares SS, Lima LD, Castro ALB. O papel da atenção básica no atendimento às urgências: um olhar sobre as políticas. J Manag Prim Health Care [Internet], 2014; 5(2): 170-7. Available from: http://www.jmphc.com/ojs/index.php/01/article/view/214/147

4. Romani HM, Sperandio JÁ, Sperandio JL, Diniz MN, Inácio MAM. Uma Visão Assistencial da Urgência e Emergência no Sistema de Saúde. Rev Bioética [Internet], 2009; 17(1): 41-53. Available from: http://revistabioetica.cfm.org.br/index. php/revista bioetica/article/view/78/82

5. Lumer S, Rodrigues PHA. O papel da saúde da família na atenção às urgências. Rev APS [Internet], 2011. 14(3): 289-95. Available from: http://aps.ufjf.emnuvens.com.br/aps/article/view/898/506

6. Farias DC, Celino SDM, Peixoto JBS, Barbosa ML e Costa GMC. Acolhimento e Resolubilidade das Urgências na Estratégia Saúde da Família. Rev Bras Educ Médica [Internet], 2015; 39 (1): 79-87. DOI: http://dx.doi.org/10.1590/1981-52712015v39n1e00472014

7. Conselho Federal de Medicina. Resolução CFM $n^{\circ} 1.671$, de 29 Julho 2003 [Internet]. Dispõe sobre a regulamentação do atendimento pré-hospitalar e dá outras providências. Conselho Federal de Medicina. Available from: http://www.saude.mg.gov. br/index.php?option=com gmg\&controller=document\&id $=417$

8. Minayo MCS, Deslandes SF e Gomes R. Pesquisa social: teoria, método e criatividade. 33 ed. Petrópolis, RJ: Vozes; 2013.

9. Aperibense PGGS, Lima IA. Nexos entre enfermagem, nutrição e serviço social, profissões femininas pioneiras na área da saúde. Rev Esc Enfer USP [Internet], São Paulo, 2008 Sept; 42(3): 474-82. DOI: http://dx.doi.org/10.1590/S0080-62342008000300009

10. Garro IMB, Camillo SO, Nóbrega MPSS. Depressão em Graduandos de Enfermagem. Acta Paul Enfermagem [Internet], São Paulo, 2006 Apr/June. 19(2): 162-7. DOI: http://dx.doi. org/10.1590/S0103-21002006000200007

11. Barreto IS, Krempel MC, Humerez DC. O Cofen e a Enfermagem na América Latina. Enfermagem em Foco COFEN [Internet], 2011. 2(4): 251-4. Available from: http://revista.portalcofen.gov. br/index.php/enfermagem/article/view/195/131

12. Witt RR. Competências da enfermeira na atenção básica: contribuição à construção das funções essenciais de Saúde Pública. Ribeirão Preto. Tese [Doutorado em Enfermagem em Saúde Pública] - Escola de Enfermagem de Ribeirão Preto, Universidade de São Paulo; 2005.

13. Mendes, EV. As redes de atenção à saúde. Brasília: Organização Pan-Americana da Saúde; 2011. 
14. Minayo MCS, Deslandes SF. Análise da implantação da rede de atenção às vítimas de acidentes e violências segundo diretrizes da Política Nacional de Redução da Morbimortalidade sobre Violência e Saúde. Ciênc \& Saúde Coletiva [Internet], Rio de Janeiro, 2009 Nov/Dec; 14(5): 1641-9. DOI: http://dx.doi. org/10.1590/S1413-81232009000500002

15. Marques GQ, Lima MADS, Ciconet RM. Agravos clínicos atendidos pelo Serviço de Atendimento Móvel de Urgência (SAMU) de Porto Alegre - RS. Acta Paul Enferm [Internet], São Paulo, 2011; 24(2): 185-91. DOI: http://dx.doi.org/10.1590/ S0103-21002011000200005

16. Ministério da Saúde (BR). Portaria GM n².048, de 05 de novembro de 2002. Política Nacional de Atenção às Urgências. Legislação de Saúde. Ministério da Saúde. Brasília: Ministério da Saúde; 2002.

17. Velloso ISC, Alves M e Sena RR. Atendimento móvel de urgência como política pública de saúde. Reme - Rev Min Enferm [Internet]. 2008; 12(4): 557-63. DOI: http://www.dx.doi.org/ $\underline{\mathrm{S} 1415-27622008000400015}$

18. Prinja S, Jeet G, Kaur M, Aggarwal AK, Manchanda N, Kumar R. Impact of referral transport system on institutional deliveries in Haryana, India. Indian J Med Res [Internet], 2014 Jun; 139(6): 883-91. PMID: 25109723

19. Ferraz L, Trintade LL, Bevilaqua E, Santer J. As demandas do homem rural: informações para a assistência nos serviços de saúde da atenção básica. Rev Min Enferm [Internet]. 2013; 17(2): 349-55. DOI: http://www.dx.doi.org/10.5935/14152762.20130026

20. Booker MJ, Shaw ARG, Purdy S. Why do patients with 'primary care sensitive' problems access ambulance services? A systematic mapping review of the literature. BMJ Open [Internet]. 2015; 31(5): e007726. DOI: 10.1136/bmjopen-2015-007726

21. Ministério da Saúde (BR). Política Nacional de Atenção às Urgências. 2. ed. ampl. Brasília: Ministério da Saúde; 2006.

22. Ministério da saúde (BR). Regulação Médica das Urgências - RMU. Secretaria de Atenção à Saúde, Departamento de Atenção Especializada. Brasília: Ministério da Saúde; 2006.

23. Magalhães Junior HM. Encaminhamentos responsáveis em um Sistema inteligente de Atenção Regulada de Urgência e Emergência. In: Melo MCB, Vasconcelos MC. Manual de Atenção às Urgências e Emergências em Pediatria. Belo Horizonte: Escola de Saúde Pública de Minas Gerais; 2005. p. 375-86.

\section{Comment on this article:}

\section{(f) $[$ in $8+\mathbf{S} P$}

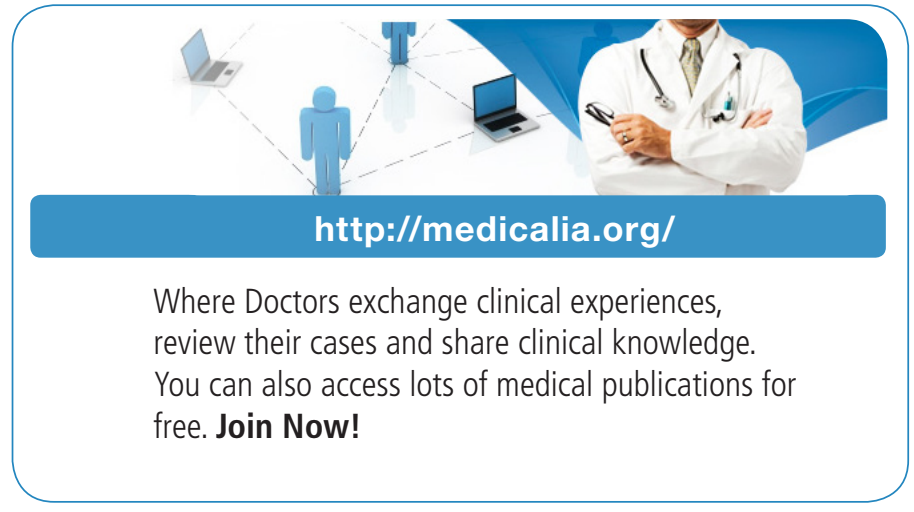

\section{Publish with iMedPub}

\section{http://www.imed.pub}

International Archives of Medicine is an open access journal publishing articles encompassing all aspects of medical science and clinical practice. IAM is considered a megajournal with independent sections on all areas of medicine. IAM is a really international journal with authors and board members from all around the world. The journal is widely indexed and classified Q1 in category Medicine. 